\title{
A Comparative Study of Pronunciation among Chinese Learners of English from Malaysia and China: The Case of Voiceless Dental Fricatives / $\theta /$ and Alveolar Liquids / $/$
}

Mohd Hilmi Hamzah*, Aini Ahmad, Mohd Hasren Yusuf

School of Languages, Civilisation and Philosophy, Universiti Utara Malaysia, 06010 Sintok, Kedah, Malaysia

*Corresponding author: hilmihamzah@uum.edu.my

\begin{abstract}
This study took up a socio-phonetic investigation among Chinese learners of English by comparing English pronunciation produced by Chinese learners from two different countries: (1) Malaysia and (2) China. Two segmental sounds in English were chosen for comparison: (1) voiceless dental fricatives / $\theta /$ and (2) alveolar liquids $/ \mathrm{r} /$; these sounds were known to be problematic for both groups of learners. The key motivation was to explore the extent to which these two groups of English learners behaved differently in terms of the selected sounds, given the differences in their nationalities, language exposure and social backgrounds. Production data were gathered from 10 Chinese learners each from Malaysia and China. They were all undergraduate students at Universiti Utara Malaysia. Two types of reading materials were used to elicit the data: (1) discreet items (i.e., an English wordlist each for $/ \theta /$ and $/ \mathrm{r} /$ ) and (2) connected speech (i.e., an English poem each for $/ \theta /$ and $/ \mathrm{r} /$ ). The data were auditorily analysed by three evaluators using a likert-scale evaluation form. The findings show that the Chinese learners from Malaysia were able to produce the / $\theta /$ tokens more successfully as compared to those from China, particularly in the connected texts. Those who failed to produce the target sound substituted it with /t/ (for the learners from Malaysia) and /s/ or /z/ (for the learners from China). As for the /r/ tokens, it was found that both groups of learners could produce the target sound correctly across both reading materials; only a few of them substituted /r/ with /1/. The study highlights the importance of understanding the difficulties faced by specific groups of learners when mastering English pronunciation for different purposes. It also calls for further experimental research in language instructions that can effectively cater the needs of English language learners with diverse backgrounds.
\end{abstract}

Keywords: English pronunciation; Chinese learners of English; voiceless dental fricatives; alveolar liquids

(C) 2017 Penerbit UTM Press. All rights reserved

\subsection{INTRODUCTION}

Non-native English speakers around the world usually have their own way of pronouncing English sounds, which can probably be accounted for by the interference of their native language. According to Lott (1983), interference refers to "the errors made by learners in using the target language and it can be traced back to the learner's native language" (p. 256). The interference of native language is also evident among Chinese learners of English. Yiing (2011) claims that it is difficult for Chinese English learners to produce some English sounds as those sounds are not available in the phoneme inventory system of their native language. Similarly, Zhang and Yin (2009) state that many English phonemes have their counterparts in Chinese language, but some of them do not share with Chinese language counterparts. For instance, the voiceless dental fricative $/ \theta$ / sound of English is not available in Chinese phoneme inventories (Yiing, 2011). Additionally, Zhang and Yin (2009) assert that "the place and manner of articulation functions are different in English and Chinese" (p. 142). For example, native speakers of Mandarin view the alveolar liquid / $\mathrm{r}$ / sound as a voiced pair to their voiceless / $/$ sound (Zhang \& Yin, 2009).

Although the difficulties faced by the Chinese learners of English in pronouncing the target language might be similar, their non-native English pronunciation might vary according to their background. Rau, Chang and Tarone (2009) claim that Chinese speakers from different backgrounds may substitute different alternatives for the target English / $\theta /$. Peust (1996) reports some variants for the production of English /0/: /f/ by Hong Kong Chinese, /t/ by Malaysia/Singapore Chinese, but /s/ by Chinese in Taiwan. In the Malaysian context, Yiing (2011) points out that "the influence of Malay language as a national language in Malaysia should not be disregarded for the Malaysian Chinese learners of English" (p. 3; for more recent studies in Malaysia, see, e.g., Pillai et al., 2012; Pillai, 2014, 2015; Tan \& Low, 2014). To illustrate, the Malaysian Chinese (henceforth MC) speakers of English have been reported to pronounce the / $\theta /$ sound of English as / $t$ / (Yiing, 2011). The Chinese learners of English from China (henceforth CC), on the other hand, might be strongly influenced by their native language; they usually use the $/ \mathrm{s} /$ sound to replace the $/ \theta /$ sound, which does not exist in their native language (Rau et al., 2009). Gao (2005) states that, Chinese languages have the retroflex initial /r/ as in the word "ri", but the Chinese /r/ is pronounced differently from the English /r/, with the tip of the tongue curling much further back than the English /r/. It is also well known that many MC learners may have problem in pronouncing the /r/ sound; they usually substitute it with the /l/ sound. For example, instead of saying "rabbit", they may potentially replace it with "labbit". 
According to Zhang and Yin (2009), many CC learners are facing difficulties in learning English in their home country. The Chinesespeaking environment makes learning process difficult for $\mathrm{CC}$ learners to use English in their daily routines. The writing systems are also different between Chinese and English; English is written alphabetically while Chinese uses a logographic system. Based on past studies (e.g., Gut \& Pillai, 2014; Pavlik, 2012), there are differences in English pronunciations between MC and CC learners. Focusing only on several English sounds, such as voiceless dental fricatives $/ \theta /$ and alveolar liquids $/ \mathrm{r} /$, an assumption can be made that these two different groups of English learners may have different ways of pronouncing English words with these sounds. However, linguists (e.g., Brannen, 2002) are still debating on whether one's nationality can affect one's English pronunciation. Hence, there is a need to investigate and compare English pronunciation of two different nationalities of Chinese English speakers.

In this study, we will explore the substitution patterns for English sounds among non-native speakers of different first languages. We aim to investigate the production of two distinctive English sounds made by two different groups of Chinese English learners. To be more specific, we seek to compare the pronunciation of voiceless dental fricatives $/ \theta /$ and alveolar liquids $/ \mathrm{r} /$ produced by $\mathrm{MC}$ and $\mathrm{CC}$ learners. The research questions of this study are as follows:

1. How do MC and CC learners pronounce the English voiceless dental fricatives $/ \theta /$ ? To what extent do changes of pronunciation occur?

2. How do MC and CC learners pronounce the English alveolar liquids /r/? To what extent do changes of pronunciation occur?

We hope that this study can help English teachers discover the different pronunciation patterns among Chinese learners of English from different nationalities. We also hope that English language practitioners can design better teaching methods and learning materials that can cater for different groups of Chinese learners of English.

\subsection{METHODOLOGY}

\subsection{Participants}

The sample of this study was selected from Universiti Utara Malaysia (UUM) Chinese students. 10 MC learners were chosen from English Communication 1 classes while $10 \mathrm{CC}$ learners were selected from Intensive English programme. They were recruited using probability sampling (simple random sampling) based on a master list from the Language Centre, UUM.

\subsection{Materials}

The instruments used in this research were two reading worksheets. The first reading worksheet included a list of English words and a poem with the presence of the $/ \theta$ / sound in three different positions; initial, medial, and final (see Appendix A). The poem presented in the first reading worksheet was adopted from Karakas (2012). The second reading worksheet included a list of English words and a poem with the presence of the $/ \mathrm{r} /$ sound in initial, medial and final positions (see Appendix B). A poem from Wan Ibrahim, Kamarudin, Devi and Ramachandran (2007) was adopted in this worksheet.

\subsection{Data Collection}

Before the data collection was conducted, a consent letter and a master list of UUM students attending English Communication 1 course and Intensive English programme were obtained from the Language Centre, UUM. The respondents were taken to a closed classroom and asked to read Reading Worksheet 1 and Reading Worksheet 2 individually. The reading session was recorded using a video camera and it took approximately an hour for each respondent.

\subsection{Data Analysis}

The pronunciation for each respondent was analysed and transcribed by three different examiners to ensure the reliability of the transcription. The respondents' pronunciations were evaluated using a five-point likert scale in an evaluation form (see Appendix C). Besides, the substitutions used in replacement of wrong pronunciations were also documented. In the following section, the results from this study will be presented in percentages, i.e., wrong pronunciation to correct pronunciation of two given tasks, which are wordlists and connected speeches.

\subsection{RESULTS}

\subsection{Voiceless Dental Fricatives / $\boldsymbol{\theta} /$}

Table 1 shows 30 words in a wordlist for $/ \theta$ / produced by 20 respondents. Under each group of speakers, there are two columns that indicate the percentages of correct pronunciation among respondents and the substitutions used. It can be observed that most of the words produced by MC learners were pronounced correctly $(70 \%)$, while $30 \%$ were wrong (the respondents substituted $/ \theta /$ with $/ \mathrm{t} /$ ). For CC respondents, only $30 \%$ of them pronounced the words correctly, while $70 \%$ pronounced the words incorrectly and substituted / $\theta /$ with either /s/or /z/. 
Table 1 Wordlist for $/ \theta /$

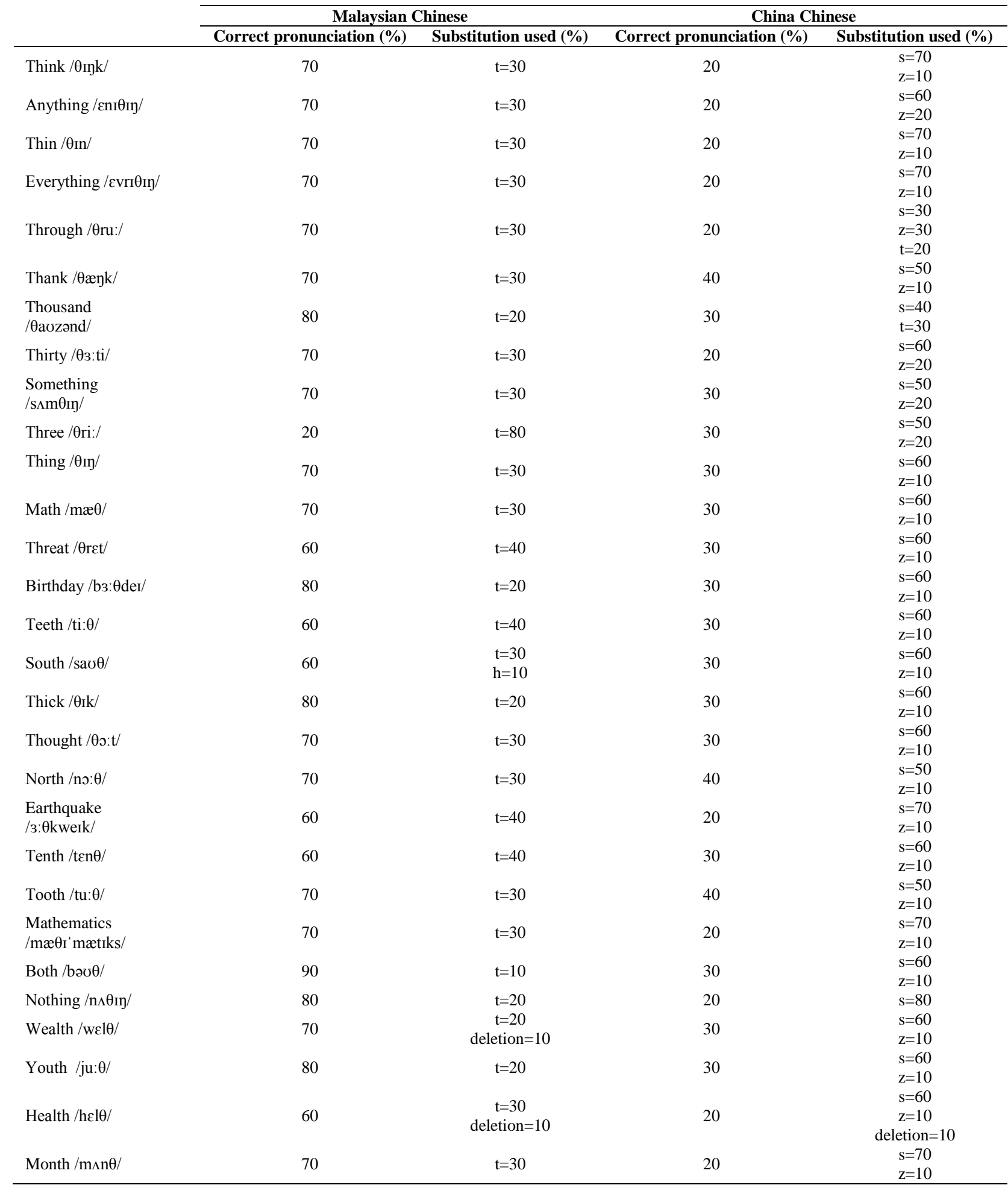

Table 2 shows 13 connected texts in a poem with the $/ \theta$ / sound pronounced by 20 respondents. It can be seen that $80 \%$ of MC learners pronounced the tokens correctly, while $20 \%$ of the respondents substituted them with $/ \mathrm{t} /$. As for CC respondents, only $20 \%$ of them pronounced the texts correctly, while $80 \%$ of them pronounced the texts incorrectly and substituted them with either $/ \mathrm{s} / \mathrm{or} / \mathrm{z} /$. 
Table 2 Connected speech for $/ \theta /$

\begin{tabular}{|c|c|c|c|c|}
\hline & \multicolumn{2}{|c|}{ Malaysian Chinese } & \multicolumn{2}{|c|}{ China Chinese } \\
\hline & Correct pronunciation (\%) & Substitution used (\%) & Correct pronunciation (\%) & Substitution used (\%) \\
\hline $\begin{array}{l}\text { two thin thumbies } \\
\text { /tu: } \theta \text { in } \theta_{\Lambda \mathrm{mb}} \mathrm{m} /\end{array}$ & 90 & $\mathrm{t}=10$ & 20 & $\begin{array}{l}\mathrm{s}=40 \\
\mathrm{z}=30 \\
\mathrm{t}=10\end{array}$ \\
\hline $\begin{array}{l}\text { My favorite thumb /mai } \\
\text { fervorit } \theta \Lambda \mathrm{m} / \\
\text { My thumbies always }\end{array}$ & 80 & $\mathrm{t}=20$ & 30 & $\begin{array}{l}s=40 \\
z=30\end{array}$ \\
\hline $\begin{array}{l}\text { soothe me /mai } \theta \Lambda \mathrm{mbIz} \\
\text { s:lweIz su:ð mi:/ }\end{array}$ & 70 & $\mathrm{t}=30$ & 10 & $\mathrm{~s}=90$ \\
\hline $\begin{array}{l}\text { My thumbies help me } \\
\text { fall asleep /mai } \theta_{\Lambda \text { mbIz }} \\
\text { help mi: fo:l əsli:p/ }\end{array}$ & 80 & $t=20$ & 20 & $\begin{array}{l}\mathrm{s}=40 \\
\mathrm{z}=30 \\
\mathrm{t}=10\end{array}$ \\
\hline $\begin{array}{l}\text { sucking thumbs is bad } \\
\text { /s } \Lambda \text { kin } \theta \Lambda \mathrm{mz} \text { Iz bæd/ }\end{array}$ & 80 & $\mathrm{t}=20$ & 20 & $\begin{array}{l}\mathrm{s}=40 \\
\mathrm{z}=30 \\
\mathrm{t}=10\end{array}$ \\
\hline $\begin{array}{l}\text { I suck my thumbs /aI } \\
\text { s } \Lambda \mathrm{k} \text { mai } \theta \Lambda \mathrm{mz} /\end{array}$ & 80 & $\mathrm{t}=20$ & 20 & $\begin{array}{l}s=50 \\
z=20 \\
t=10\end{array}$ \\
\hline $\begin{array}{l}\text { don't suck thy thumbs } \\
\text { /dəunt s } \Lambda \text { k ठai } \theta_{\Lambda \mathrm{mz} /}\end{array}$ & 80 & $\mathrm{t}=20$ & 20 & $\begin{array}{l}s=60 \\
z=10 \\
t=10\end{array}$ \\
\hline $\begin{array}{l}\text { front teeth out } \\
\text { /frsnt ti: } \theta \text { avt/ }\end{array}$ & 80 & deletion $=20$ & 20 & $\begin{array}{l}\mathrm{s}=50 \\
\mathrm{z}=30\end{array}$ \\
\hline $\begin{array}{l}\text { get straight teeth } \\
\text { /get streit ti: } \theta /\end{array}$ & 80 & deletion $=20$ & 30 & $\begin{array}{l}s=50 \\
z=20\end{array}$ \\
\hline $\begin{array}{l}\text { braces on your mouth } \\
\text { /'breisiz pn jo: mav } \theta \text { / }\end{array}$ & 100 & 0 & 20 & $\begin{array}{l}s=50 \\
z=10 \\
t=20\end{array}$ \\
\hline 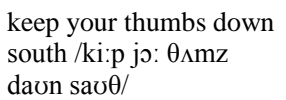 & 50 & $s=50$ & 20 & $\begin{array}{l}\mathrm{s}=40 \\
\mathrm{z}=30 \\
\mathrm{t}=10\end{array}$ \\
\hline $\begin{array}{l}\text { people thinking } \\
\text { /pi:pl } \theta \text { Inkin/ }\end{array}$ & 80 & $\mathrm{t}=20$ & 20 & $\begin{array}{l}\mathrm{s}=40 \\
\mathrm{z}=30 \\
\mathrm{t}=10\end{array}$ \\
\hline $\begin{array}{l}\text { my teeth look like a } \\
\text { rabbit's } \\
\text { /mai ti: } \theta \text { lok laik ə } \\
\text { 'ræbitz/ }\end{array}$ & 80 & $\begin{array}{l}\mathrm{s}=10 \\
\mathrm{t}=10\end{array}$ & 30 & $\begin{array}{l}s=50 \\
z=20\end{array}$ \\
\hline
\end{tabular}

\subsection{Alveolar Liquids /r/}

Table 3 shows a wordlist for $/ \mathrm{r} /$ pronounced by 20 respondents. In most cases, all MC speakers pronounced the words correctly. One MC speaker, however, pronounced "lorry" as "lolly", substituted /r/ with /1/. As for CC respondents, the same trend was observed: mostly all of them pronounced the words correctly. One CC respondent, however, pronounced the word "rose" as "lose", substituting /r/ with /l/.

Table 3 Wordlist for $/ \mathrm{r} /$

\begin{tabular}{|c|c|c|c|c|}
\hline & \multicolumn{2}{|c|}{ Malaysian Chinese } & \multicolumn{2}{|c|}{ China Chinese } \\
\hline & Correct pronunciation (\%) & Substitution used (\%) & Correct pronunciation (\%) & Substitution used (\%) \\
\hline Raccoon/raku:n/ & 100 & 0 & 100 & 0 \\
\hline $\begin{array}{l}\text { Superman } \\
\text { /sju:pəmæn/ }\end{array}$ & 10 & Deletion $=90$ & 100 & 0 \\
\hline Random /rændəm/ & 100 & 0 & 100 & 0 \\
\hline Rose /rovz/ & 100 & 0 & 90 & $\mathrm{l}=10$ \\
\hline Rain /rem/ & 100 & 0 & 100 & 0 \\
\hline Raise/reIz/ & 100 & 0 & 100 & 0 \\
\hline Rainbow/resnbəo/ & 100 & 0 & 100 & 0 \\
\hline Borrow /borəo/ & 100 & 0 & 100 & 0 \\
\hline Sorrow /sprəv/ & 100 & 0 & 100 & 0 \\
\hline Rubber/rıbo/ & 100 & 0 & 100 & 0 \\
\hline Roasted /rəostıd/ & 100 & 0 & 100 & 0 \\
\hline Roll /rəəl/ & 100 & 0 & 100 & 0 \\
\hline Lorry /lpri/ & 80 & $1=20$ & 90 & $l=10$ \\
\hline Sorry /spri/ & 100 & 0 & 100 & 0 \\
\hline Ripe /rarp / & 100 & 0 & 100 & 0 \\
\hline Trap /træp/ & 90 & Deletion $=10$ & 90 & Deletion $=10$ \\
\hline Roaring /ro:rıy/ & 100 & 0 & 90 & Deletion $=10$ \\
\hline Eraser /IreIzo/ & 90 & Deletion $=10$ & 100 & 0 \\
\hline
\end{tabular}




\begin{tabular}{|c|c|c|c|c|}
\hline Brisk /brisk/ & 100 & 0 & 100 & 0 \\
\hline Fragile /frædzarl/ & 100 & 0 & 100 & 0 \\
\hline Drape /dreip/ & 100 & 0 & 100 & 0 \\
\hline Present /preznt/ & 100 & 0 & 100 & 0 \\
\hline Browser /braozə/ & 90 & Deletion $=10$ & 100 & 0 \\
\hline Ice-cream /aiskri:m/ & 100 & 0 & 100 & 0 \\
\hline Sorrow /sprəv/ & 100 & 0 & 100 & 0 \\
\hline $\begin{array}{l}\text { Strawberry } \\
\text { /stro:bəri/ }\end{array}$ & 100 & 0 & 90 & $\mathrm{l}=10$ \\
\hline Parents /peərənts/ & 100 & 0 & 100 & 0 \\
\hline Sprinter /sprintə/ & 100 & 0 & 100 & 0 \\
\hline Very /veri/ & 100 & 0 & 100 & 0 \\
\hline Terrace /tcrəs/ & 100 & 0 & 100 & 0 \\
\hline
\end{tabular}

Table 4 shows connected texts in a poem with the /r/ sound pronounced by 20 respondents. It can be seen that MC speakers produced most texts correctly. As for CC respondents, the trend was quite similar to that observed for MC learners.

Table 4 Connected speech for $/ \mathrm{r} /$

\begin{tabular}{|c|c|c|c|c|}
\hline & \multicolumn{2}{|c|}{ Malaysian Chinese } & \multicolumn{2}{|c|}{ China Chinese } \\
\hline & Correct pronunciation (\%) & Substitution used (\%) & Correct pronunciation (\%) & Substitution used (\%) \\
\hline $\begin{array}{l}\text { I've got whiskers /aIv } \\
\text { gpt wiskərz/ }\end{array}$ & 0 & Deletion $=100$ & 0 & Deletion $=100$ \\
\hline $\begin{array}{l}\text { I've got fur } \\
\text { /arv gdt f3r:/ }\end{array}$ & 0 & Deletion $=100$ & 0 & Deletion $=100$ \\
\hline $\begin{array}{l}\text { I don't bark } \\
\text { /aI dəont bar:k/ }\end{array}$ & 0 & Deletion $=100$ & 0 & Deletion $=100$ \\
\hline $\begin{array}{l}\text { I do purr } \\
\text { /ai du: p3r:/ }\end{array}$ & 0 & Deletion $=100$ & 0 & Deletion $=100$ \\
\hline $\begin{array}{l}\text { Make me angry /merk } \\
\text { mi: æygri/ }\end{array}$ & 100 & 0 & 100 & 0 \\
\hline $\begin{array}{l}\text { a rat to catch } \\
\text { /ə ræt tu: kæty/ }\end{array}$ & 100 & 0 & 100 & 0 \\
\hline $\begin{array}{l}\text { My world is watery } \\
\text { /maI w3:ld Iz wo:təri// }\end{array}$ & 0 & Deletion $=100$ & 100 & 0 \\
\hline $\begin{array}{l}\text { I prefer a bowl } \\
\text { /ai pri'f3:r a bəol/ }\end{array}$ & 100 & 0 & 100 & 0 \\
\hline $\begin{array}{l}\text { carrots I like } \\
\text { /kærəts ar lark/ }\end{array}$ & 100 & 0 & 100 & 0 \\
\hline $\begin{array}{l}\text { front teeth are sharp } \\
/ \text { fr } \Delta \text { nt ti: } \theta a: \int a: p /\end{array}$ & 100 & 0 & 100 & 0 \\
\hline $\begin{array}{l}\text { My ears are long /maI } \\
\text { Iəz a: loy/ }\end{array}$ & 100 & 0 & 0 & Deletion $=100$ \\
\hline $\begin{array}{l}\text { my fur has no lice /maI } \\
\text { f3: hæz nəひ lais/ }\end{array}$ & 100 & 0 & 100 & 0 \\
\hline $\begin{array}{l}\text { fly over } \\
\text { /flai əovə/ }\end{array}$ & 100 & 0 & 100 & 0 \\
\hline $\begin{array}{l}\text { in front of me } \\
\text { /In frsnt pv mi:/ }\end{array}$ & 100 & 0 & 100 & 0 \\
\hline $\begin{array}{l}\text { can repeat } \\
\text { /kæn ripi:t/ }\end{array}$ & 100 & 0 & 100 & 0 \\
\hline
\end{tabular}

\subsection{DISCUSSIONS}

In this study, we have observed that MC learners were able to pronounce the $/ \theta$ / sound more easily compared to CC learners. The data highlighted that majority of MC learners (60\%-70\%) pronounced all 30 English words with the / $\theta$ / sound correctly, while less than half of CC learners (20\%-40\%) pronounced the words correctly. As for the connected speech, majority of MC learners (50\%-100\%) pronounced all the texts with the $/ \theta /$ sound correctly. In contrast, there were very few $\mathrm{CC}$ learners $(10 \%-30 \%)$ who pronounced the $/ \theta /$ sound in the connected speech correctly. It is clear that MC speakers pronounced the $/ \theta$ / sound more clearly compared to CC learners.

In term of text type, the results show that $\mathrm{MC}$ learners pronounced the $/ \theta /$ sound better in a connected text compared to a wordlist. $\mathrm{CC}$ learners, however, pronounced the $/ \theta /$ sound better in a wordlist compared to a poem. This observation could be the result of the learners' awareness of the text type when pronouncing these words. That is, $\mathrm{MC}$ learners pronounced the $/ \theta /$ sound better in a poem as they were more familiar with the words after reading a long wordlist containing the same word. In contrast, CC learners pronounced the wordlist better than the poem because the wordlist probably contained simpler words compared to the poem. We also observed that $80 \%$ of MC learners who failed to pronounce the $/ \theta$ / sound correctly chose to substitute it with $/ \mathrm{t} / .20 \%$ of them chose to totally delete the sound while pronouncing the words. Meanwhile, majority of CC learners (40\%-70\%) chose to substitute the $/ \theta /$ sound with /s/, while others (10-\%-30\%) substituted the sound with $/ \mathrm{z} /$. 
Our data generally accord well with some of the previous findings on the pronunciation of the $/ \theta$ / sound among Chinese learners. According to Yiing (2011), it is common for MC learners to replace $/ \theta /$ with $/ \mathrm{t} /$ as they do not have such a sound in Mandarin. In addition, Gao (2005) reports that it is common for $\mathrm{CC}$ learners to replace $/ \theta /$ with $/ \mathrm{s} /$. However, CC learners rarely replace $/ \theta /$ with $/ \mathrm{z} /$ as found in this study.

Our findings reveal that both MC and CC learners were able to pronounce the wordlist with the $/ \mathrm{r} /$ sound correctly; mostly all of them pronounced the words with the /r/ sound correctly (80\%-100\%). Additionally, $10 \%$ of both groups of learners failed to pronounce the $/ \mathrm{r}$ / sound correctly in one word only, i.e., "lorry". Instead of pronouncing the /r/ sound correctly, the respondent chose to substitute it with the /l/ sound. This is not surprising since it is well known that most Chinese learner of English have difficulties in differentiating /l/ and / $/$ / sounds (e.g., Wan Ibrahim et al., 2007). Moreover, $10 \%$ of the respondents failed to pronounce the /r/ sound in the consonant cluster "fragile". Instead of pronouncing the cluster, the respondent chose to totally delete the /r/ sound from the word "fragile".

As the respondents were asked to read aloud from a poem, it was found that all respondents managed to pronounce all the words with the /r/ sound in initial and middle positions correctly. However, all of them did not pronounce the /r/ sound in the final position, which was due to the respondents' preference for the British English model that does not pronounce the /r/ sound in the final position. Hence, it can be concluded that both groups of Chinese learners of English are not having difficulties in pronouncing alveolar liquids $/ \mathrm{r} /$.

Our results nevertheless are not on line with those found in Wan Ibrahim et al. (2007); MC learners were found to face more problems in pronouncing /r/ compared to CC learners. Besides, Wan Ibrahim et al. (2007) also highlight that both groups of Chinese learners of English have problems in pronouncing the $/ \mathrm{r} /$ sound in a wordlist compared to a connected speech, in contrast with our results that show that both groups of English learners can pronounce the /r/ sound easily, either in a wordlist or in a poem.

\subsection{CONCLUSION}

Our study focuses on the English pronunciation between two groups of Chinese learners of English and we believe that the results presented in this study will contribute to the development of English language teaching among Chinese learners of English especially in Malaysia. Since many English learners from China come to learn English in Malaysia, it is hoped that this study will help English teachers in Malaysia to acknowledge the different language abilities between two different groups of Chinese learners of English.

Based on the findings of this study, a few recommendations are put forward to assist English teachers in accommodating the learning needs of Chinese students from China and Malaysia. Firstly, it is recommended that teachers need to clearly highlight the difference between $/ \theta /, / \mathrm{t} /, / \mathrm{s} /$ and $/ \mathrm{z} /$ to Chinese learners of English. They are recommended to explain the different quality, manner and articulators needed in pronouncing the four different English consonants.

Besides, English teachers may also want to highlight the difference between the liquids /r/ and /l/. As highlighted earlier, many Chinese learners, regardless of their nationality, face difficulties in differentiating both sounds. Besides, it is also suggested for teachers to focus more on the pronunciation of consonant clusters as some students face difficulties in pronouncing two consonants together.

This research only highlights two English consonants, which are $/ \theta /$ and $/ \mathrm{r} /$. During the process of data collection, it was observed that the respondents faced more problems in pronouncing other sounds including vowels and other consonants. Hence, it is suggested for future research to focus on the pronunciation of other English sounds especially those that do not exist in the respondents' native language.

All in all, it can be concluded that the respondents from both groups of Chinese learners have more difficulties in pronouncing the $/ \theta /$ sound compared to the /r/ sound. Besides, it can also be concluded that $\mathrm{CC}$ learners are facing more difficulties in pronouncing both consonants compared to MC learners.

\section{References}

Brannen, K. (2002).The Role Of Perception In Differential Substitution. Canadian Journal of Linguistics, 47, 1-46.

Gao, L.(2005). Pronunciation Difficulties Analysis: A Case Study Using Native Language Linguistics Background To Understand A Chinese English Learners Pronunciation Problems. CELEA Journal, 28(2), 76-84.

Gut, U., \& Pillai, S. (2014). Prosodic Marking Of Information Structure By Malaysian Speakers of English. Studies in Second Language Acquisition, 36(2), 283-302.

Karakas, A.(2012). Teaching of TH sounds in English. Retrieved 25/5/2016 fromhttps://www.slideshare.net/alikarakas85/teaching-of-th-sounds-in-english-by-alikarakas.

Lott, D.(1983).Analysing and Counteracting Interference Errors. ELT Journal, 37(3), 256-261.

Pavlik, A. (2012). Teaching English Language Learners From China. Retrieved http://scholars.unh.edu/cgi/viewcontent.cgi?article=1068\&context=honors

Peust, C. (1996). Sum: th-Substitution. The Linguist List, 7, 1108-1110.

Pillai, S. (2014). The Monophthongs And Diphthongs Of Malaysian English: An Instrumental Analysis. In Hajar Abdul Rahim, \& Shakila Abdul Manan (Eds.), English in Malaysia: Postcolonial and Beyond, 55-86. Bern: Peter Lang.

Pillai, S. (2015). Rhothicity in Malaysian English: The Emergence Of A New Norm? In U. Gut, R. Fuchs, \& E.-M. Wunder (Eds.), Universal or Diverse Paths to English linguistics (pp. 23-40). Berlin: Mouton de Gruyter.

Pillai, S., Zuraidah Mohd Don, \& Knowles, G. (2012).Towards Building A Model Of Standard Malaysian English Pronunciation. In Zuraidah Mohd Don (Ed.), English in Multicultural Malaysia: Pedagogy And Applied, 195-211. Kuala Lumpur: University of Malaya Press.

Rau, V., Chang, H.-H. A., Tarone, E. E. (2009). Think or Sink: Chinese Learners' Acquisition Of The English Voiceless Interdental Fricative. Language Learning, 59(3), $581-621$.

Tan, S. K., \& Low, E.-L. (2014). Rhythmic Patterning in Malaysian and Singapore English. Language \& Speech, 57(2), $196-214$.

Wan Ibrahim, N. R., Kamarudin, M. F., Devi, S., Ramachandran, S. D. (2007). A Comparative Study Of Chinese ESL Learners From Malaysia And The People's Republic Of China In Their Pronunciation of /r/ \& /1/. The Second Biennial International Conference on Teaching and Learning of English in Asia: Exploring New Frontiers (TELiA2), 1-16. Alor Setar: Faculty of Modern Language, Universiti Utara Malaysia.

Yiing, I. K. (2011). An Analysis Of Pronunciation Errors In English Of Six UTAR Chinese Studies Undergraduates (Unpublished Bachelor Degree's Research Project). Universiti Tunku Abdul Rahman, Kuala Lumpur.

Zhang, F., \&Yin, P.(2009).A Study Of Pronunciation Problems Of English Learners in China. Asian Social Science, 5(6), $141-146$. 


\section{Appendix}

Appendix A: Reading Worksheet 1

(i) Wordlist

1. Think

2. Three

3. Thing

4. Thin

5. Thick

6. Thought

7. Through

8. Thank

9. Threat

10. Thousand

11. Thirty

12. Something

13. Nothing

14. Birthday

15. Anything

16. Earthquake

17. Everything

18. Mathematics

19. With

20. Teeth

21. South

22. North

23. Math

24. Tenth

25. Tooth

26. Both

27. Wealth

28. Youth

29. Health

30. Month

(ii) Poem

\section{My Thumbies}

Child:

I have two thin thumbies

They're with me day and night

My favorite thumb is on my left

The other's on my right

My thumbies always soothe me

when I am feeling sad

They help me to protect myself when I am feeling mad

My thumbies help me fall asleep

when I am feeling tired

I do not know how better friends

could ever be desired

My mother says it's time to quit

that sucking thumbs is bad

And every time I suck my thumbs

my mom gets very mad.

\section{Mom:}

You've got to quit

Don't suck thy thumbs

your left one or your right

It's pushing all your front teeth out

It's ruining your bite

It might take years to get straight teeth

with braces on your mouth 
It isn't fun

Believe me, son

So keep your thumbs down south.

\section{Child:}

I'm 5 years old

It's time to quit

of all the silly habits

I don't want people thinking

that my teeth look like a rabbit's.

Appendix B: Reading Worksheet 2

(i) Wordlist
1. Raccoon
2. Superman
3. Random
4. Rose
5. Rain
6. Raise
7. Rainbow
8. Borrow
9. Sorrow
10. Rubber
11. Roasted
12. Roll
13. Lorry
14. Sorry
15. Ripe
16. Trap
17. Roaring
18. Eraser
19. Brisk
20. Fragile
21. Drape
22. Present
23. Browser
24. Ice-cream
25. Sorrow
26. Strawberry
27. Parents
28. Sprinter
29. Very
30. Terrace

(ii) Poem

I've got whiskers and I've got fur

I don't bark but I do purr

Make me angry and I'll scratch

My hobby is waiting for a rat to catch.

My world is watery and wet

That's why you can't see me sweat

I can live in a tank but I prefer a bowl

So that I can show off my fins and scales of gold.

I don't eat meat but carrots I like

My two front teeth are sharp like spikes

My ears are long and my fur has no lice

I make a good pet because I'm gentle and nice.

I've claws for toes and wings instead of hands

So I can fly over the seas and land 
Mind your language when in front of me you speak

For I can repeat even though my mouth is a hooked beak.

Appendix C: Evaluation Form

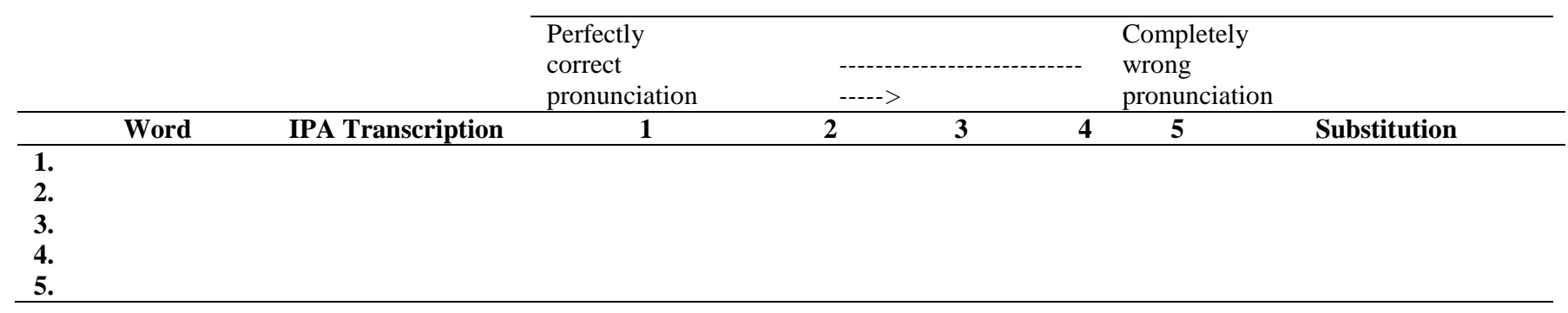

